Research article

\title{
Differential responses of pea seedlings to salicylic acid under UV-B stress
}

\author{
Chanda Bano, N. B. Singh* and Sunaina \\ Plant Physiology Laboratory, Department of Botany, University of Allahabad, Uttar Pradesh, India \\ *Corresponding Author: singhnb.au2016@gmail.com \\ [Accepted: 05 November 2016]

\begin{abstract}
In nature, plants are continuously exposed to solar light. They cannot avoid exposure to UV-B radiation. The purpose of this investigation was to examine how UV-B radiation affects seed germination, seedling growth, protein and sugar contents and activities of antioxidant enzymes in pea (Pisum sativum) seedlings. Salicylic acid mediated physiological responses in UVB stressed pea seedlings. UV-B exposure adversely affected germination and physiology of Pisum sativum L. Salicylic acid mitigated the impacts of UV-B stress. Seed germination decreased with increased duration of UV-B exposure. Enhanced activities of antioxidant enzymes in response to UV-B radiation played a protective role against UV-B radiation.
\end{abstract}

Keywords: Antioxidants - Oxidative stress - Pisum sativum L. - UV-B radiation - Salicylic acid.

[Cite as: Bano C, Singh NB \& Sunaina (2016) Differential responses of pea seedlings to salicylic acid under UV-B stress. Tropical Plant Research 3(3): 586-591]

\section{INTRODUCTION}

Plants are exposed to various abiotic and biotic stresses including solar ultraviolet-B (UV-B) radiation in the natural environment. UV-B radiation is the biggest challenge to life forms on the earth. Over the last few decades degradation of ozone layer leads to enhanced solar UV-B radiation on the earth (McKenzie et al. 2003, Liu et al. 2013). The damage of the ozone layer caused by human activities may result in increased level of ultraviolet radiation reaching the earth surface which is harmful for all living beings including crop plants (Shaukat et al. 2011). UV-B exposure alters biochemical processes in crop plants and affects the morphological parameters (Casati \& Walbot 2003, Zu et al. 2010). The exposure of plant to UV-B damages macromolecules viz., nucleic acid, lipid and proteins (Ries et al. 2000, Frohnmeyer \& Staiger 2003) decreases photosynthetic rate (Feng et al. 2003) and alters activities of several antioxidant enzymes (Agrawal \& Mishra 2009). The UV-B radiation has adverse impact on growth and decreases productivity of crop plants (Shaukat et al. 2011).

Plant growth regulators mitigate adverse effects of various environmental stresses. Salicylic acid (SA), a secondary phenolic metabolite, is considered as plant hormone. It is naturally found in plants and acts as a signaling molecule (Davies 2004, Amin et al. 2013). SA plays an important role in regulating the metabolic activities of plants (Davies 2004, Amin et al. 2013). SA application enhances the biomass production and yield in a variety of plants like maize (Amin et al. 2013), wheat (Arfan et al. 2007) under adverse conditions. SA also activates the defense system of plants to protect them from deleterious impact of abiotic stress.

Pisum sativum L. (pea) is one of the most economically important pulse crops in India because of its high protein content. Cultivation of pea is common in India due to its ability to fix atmospheric nitrogen. It is used as soil primer for other crops.

The aim of the present study was to examine the impact of UV-B exposure on seed germination and growth of pea and the stress responses of SA in UV-B stressed pea seedlings. This study may help regulate the tolerance of abiotic stress like UV-B by plant growth hormone.

\section{MATERIALS AND METHODS}

Seeds and chemical

Seeds of Pisum sativum L. cv. Rachana were procured from the Seed Agency at Allahabad, Uttar Pradesh, 
India. Salicylic acid (molecular weight 138.121 g.mol ${ }^{-1}$ ) was purchased from Loba Chemie Pvt. Ltd., Mumbai, India.

\section{Salicylic acid and ultraviolet-B treatments}

Salicylic acid was prepared by dissolving a requisite amount of $\mathrm{SA}$ in $1.0 \mathrm{~mL}$ of ethanol and the volume was made $100 \mathrm{~mL}$ with double distilled water and used for treatment. Seeds were exposed to UV-B radiation for 15 , 30, 60 and 90 min. Fluorescent UV-B tube (TL 40 W/12 Philips, Holland) was used for UV-B irradiation. The UV-B tube was wrapped with cellulose acetate filter (Johnston Industrial Plastics, Toronto, Canada) to avoid all incidents of UV-C $(<280 \mathrm{~nm})$. The UV-B irradiation intensity was measured with the help of power meter (Spectra Physics, USA model 407, A-2).

\section{Petri-plate assay}

Seeds were soaked in two groups each in $100 \mathrm{~mL}$ of SA $(0.5 \mathrm{mM})$. The seeds soaked in double distilled water (DDW) for 4 hours, separately. After completion of course of time the seeds of the two groups were further divided into five sets. Out of five, four sets of each group was exposed to UV-B radiation for 15, 30, 60 and $90 \mathrm{~min}$. The complete experimental setup has ten different combinations such as: control (without treatment), SA (0.5 mM), UV-B 1 (15 min), UV-B 2 (30 min), UV-B 3 (60 min), UV-B 4 (90 min), UV-B $1+S A$, $\mathrm{UV}-\mathrm{B}_{2}+\mathrm{SA}, \mathrm{UV}-\mathrm{B}_{3}+\mathrm{SA}, \mathrm{UV}-\mathrm{B}_{4}+\mathrm{SA}$. Ten seeds of each treatment were placed at equal distance in sterilized petriplates (dia $9 \mathrm{~cm}$, depth $1.5 \mathrm{~cm}$ ) lined with double layer of Whatman No. 1 filter papers. Filter papers were moistened with $5 \mathrm{~mL}$ of SA for respective treatments and DDW in control and incubated at $28^{\circ} \pm 2^{\circ} \mathrm{C}$ for germination in growth chamber. The experiment was conducted in replicate of three. Germination was initiated at $48 \mathrm{hrs}$ after sowing. Germination and seedling growth were recorded till 7 days after sowing at the interval of 24 hours. Radicle and plumule length was recorded with the help of metric scale.

\section{Protein content}

Protein content was determined according to the method of Lowry et al. (1951). The amount of protein was calculated with reference to the standard curve obtained from bovine serum albumin.

\section{Sugar content}

The determination of total soluble sugars (TSS) was done following Hedge \& Hofreiter (1962). About $0.1 \mathrm{~g}$ radicle was homogenized in $5 \mathrm{~mL} \mathrm{95 \%} \mathrm{(v/v)} \mathrm{ethanol.} \mathrm{After} \mathrm{centrifugation,} 1 \mathrm{~mL}$ supernatant was mixed with 4 $\mathrm{mL}$ anthrone reagent and heated on boiling water bath for $10 \mathrm{~min}$. Absorbance was recorded at $620 \mathrm{~nm}$ after cooling. The amount of sugar was determined by the standard curve prepared from glucose.

\section{Extraction and assay of antioxidant enzymes}

Fresh sample of radicle $(0.25 \mathrm{~g})$ was homogenized with $0.1 \mathrm{M}$ sodium phosphate buffer containing $1 \%(\mathrm{w} / \mathrm{v})$ polyvinyl pyrrolidone ( $\mathrm{pH} 7.0)$ in a pre-cooled mortar and pestle. The extract was centrifuged at $4^{\circ} \mathrm{C}$ at $14,000 \mathrm{~g}$ for $30 \mathrm{~min}$ in cooling centrifuge (Remi instruments $\mathrm{C} \mathrm{24}$ ). The supernatant was used for the assay of antioxidant enzymes viz., superoxide dismutase (SOD), catalase (CAT), ascorbate peroxidase (APX) and guaiacol peroxidase (GPX) activities.

The SOD activity (EC 1.15.1.1) was estimated by the nitroblue tetrazolium (NBT) photochemical assay following Beyer and Fridovich (1987). The reaction mixture (4 mL) consisted of $20 \mathrm{mM}$ methionine, $0.15 \mathrm{mM}$ ethylene diamine-tetra acetic acid (EDTA), $0.12 \mathrm{mM} \mathrm{NBT}$ and $0.5 \mathrm{~mL}$ supernatant. The test tubes were exposed to fluorescent lamps for $30 \mathrm{~min}$ and identical unilluminated assay mixture served as blank. One unit of enzyme was measured as the amount of enzyme which caused $50 \%$ inhibition of NBT reduction.

Catalase (CAT, EC1.11.1.6) activity was assayed following the method by Cakmak \& Marschner (1992). Assay mixture $\left(2 \mathrm{~mL}\right.$ ) contained $25 \mathrm{mM}$ sodium phosphate buffer $(\mathrm{pH} 7.0), 10 \mathrm{mM} \mathrm{H}_{2} \mathrm{O}_{2}$, and $0.5 \mathrm{~mL}$ enzyme extract. The rate of $\mathrm{H}_{2} \mathrm{O}_{2}$ decomposition for $1 \mathrm{~min}$ was monitored at $240 \mathrm{~nm}$ and calculated using extinction coefficient of $39.4 \mathrm{mM}^{-1} \mathrm{~cm}^{-1}$ and expressed as enzyme unit $\mathrm{mg}^{-1}$ protein. One unit of CAT was determined as the amount of enzyme required to oxidize $1 \mathrm{mM} \mathrm{H}_{2} \mathrm{O}_{2} \min ^{-1}$.

Ascorbate peroxidase (APX, EC1.11.1.11) activities were assayed following Nakano \& Asada (1981). Assay mixture $(2 \mathrm{~mL}$ ) contained $25 \mathrm{mM}$ sodium phosphate buffer ( $\mathrm{pH} 7.0), 0.1 \mathrm{mM}$ EDTA, $0.25 \mathrm{mM}$ ascorbate, 1.0 $\mathrm{mM} \mathrm{H}_{2} \mathrm{O}_{2}$, and $0.2 \mathrm{~mL}$ enzyme extract. $\mathrm{H}_{2} \mathrm{O}_{2}$ was the last component to be added. The absorbance was recorded for $1 \mathrm{~min}$ at $290 \mathrm{~nm}$ (extinction coefficient of $2.8 \mathrm{mM}^{-1} \mathrm{~cm}^{-1}$ ). Enzyme specific activity was measured as enzyme unit per one milligram protein as the amount of enzyme required to oxidize $1 \mathrm{mM} \mathrm{H}_{2} \mathrm{O}_{2} \min ^{-1}$. 
Guaiacol peroxidase (GPX, EC 1.11.1.7) activities were assayed following Hemeda and Klein (1990). The reaction mixture $(2 \mathrm{~mL})$ contained $25 \mathrm{mM}$ sodium phosphate buffer ( $\mathrm{pH} 7.0), 0.1 \mathrm{mM}$ EDTA, 0.05\% (v/v) guaiacol, $1.0 \mathrm{mM} \mathrm{H}_{2} \mathrm{O}_{2}$, and $0.2 \mathrm{~mL}$ of enzyme extract. The increase in absorbance due to oxidation of guaiacol was monitored at $470 \mathrm{~nm}$. The enzyme activities were measured using extinction coefficient of $26.6 \mathrm{mM}^{-1} \mathrm{~cm}^{-1}$ and expressed as enzyme unit per mg protein.

\section{RESULTS}

UV-B decreased seed germination in dose dependent manner. However, in combination with SA gradual increase in germination was recorded (Table 1). Maximum 53.84\% reduction in seed germination was observed in the pea seedlings exposed in UV-B for $90 \mathrm{~min}$. Growth was measured in terms of radicle and plumule length. UV-B radiation induced impact on growth of pea seedlings was measured and results are presented in tables 1 . UV-B significantly declined the radicle and plumule length which was concentration dependent. Maximum $59.11 \%$ and $90.66 \%$ decrease in radicle and plumule length in the pea seedlings over control was recorded respectively in 90 min single UV-B treatment. Application of SA with UV-B exposure exhibited positive effects on radicle and plumule length of the seedlings.

Table 1. Mitigating effects of salicylic acid on UV-B stressed Pisum sativum L.

\begin{tabular}{cccccc}
\hline Treatments & Seed germination \% & Radicle length $(\mathbf{c m})$ & $\begin{array}{c}\text { Plumule length } \\
(\mathbf{c m})\end{array}$ & $\begin{array}{c}\text { Protein } \\
\left(\mathbf{m g . g}^{-1} \mathbf{F W}\right)\end{array}$ & $\begin{array}{c}\text { Sugar } \\
\left(\mathbf{m g . g} \mathbf{g}^{-1} \mathbf{F W}\right)\end{array}$ \\
\hline $\mathrm{C}$ & $97.5 \pm 0.21 \mathrm{a}$ & $9.05 \pm 0.31 \mathrm{~b}$ & $3.75 \pm 0.02 \mathrm{~b}$ & $21.47 \pm 0.05 \mathrm{~b}$ & $29.66 \pm 0.26 \mathrm{~b}$ \\
\hline $\mathrm{S}$ & $100.0 \pm 0.23 \mathrm{a}$ & $10.3 \pm 0.57 \mathrm{a}$ & $4.4 \pm 1.0 \mathrm{a}$ & $25.80 \pm 1.48 \mathrm{a}$ & $32.80 \pm 0.29 \mathrm{a}$ \\
\hline $\mathrm{UV}_{1}$ & $82.5 \pm 0.33 \mathrm{~b}$ & $7.85 \pm 0.20 \mathrm{c}$ & $2.05 \pm 0.60 \mathrm{bc}$ & $16.34 \pm 0.36 \mathrm{c}$ & $28.20 \pm 0.53 \mathrm{bcd}$ \\
$\mathrm{UV}_{2}$ & $72.5 \pm 1.43 \mathrm{~d}$ & $7.1 \pm 0.17 \mathrm{c}$ & $1.65 \pm 0.83 \mathrm{c}$ & $9.33 \pm 1.48 \mathrm{~d}$ & $26.33 \pm 0.26 \mathrm{de}$ \\
$\mathrm{UV}_{3}$ & $57.5 \pm 1.33 \mathrm{f}$ & $5.2 \pm 0.05 \mathrm{de}$ & $1.25 \pm 0.54 \mathrm{de}$ & $6.03 \pm 0.014 \mathrm{e}$ & $24.10 \pm 0.27 \mathrm{fg}$ \\
$\mathrm{UV}_{4}$ & $45.0 \pm 0.76 \mathrm{~g}$ & $3.7 \pm 0.34 \mathrm{f}$ & $0.35 \pm 0.14 \mathrm{e}$ & $4.23 \pm 0.014 \mathrm{f}$ & $20.67 \pm 0.26 \mathrm{~h}$ \\
\hline $\mathrm{UV}_{1}+\mathrm{S}$ & $85.0 \pm 0.32 \mathrm{~b}$ & $8.1 \pm 0.41 \mathrm{c}$ & $3.4 \pm 0.28 \mathrm{abc}$ & $19.34 \pm 1.45 \mathrm{~b}$ & $29.16 \pm 0.02 \mathrm{bc}$ \\
$\mathrm{UV}_{2}+\mathrm{S}$ & $77.5 \pm 1.43 \mathrm{c}$ & $7.85 \pm 0.02 \mathrm{c}$ & $2.6 \pm 0.80 \mathrm{~cd}$ & $10.66 \pm 1.47 \mathrm{~d}$ & $27.64 \pm 0.08 \mathrm{cde}$ \\
$\mathrm{UV}_{3}+\mathrm{S}$ & $62.50 \pm 1.3 \mathrm{e}$ & $6.1 \pm 0.23 \mathrm{~d}$ & $2.7 \pm 0.11 \mathrm{~cd}$ & $7.95 \pm 0.34 \mathrm{e}$ & $25.72 \pm 0.20 \mathrm{ef}$ \\
$\mathrm{UV}_{4}+\mathrm{S}$ & $55.0 \pm 0.67 \mathrm{f}$ & $4.35 \pm 0.54 \mathrm{ef}$ & $0.55 \pm 0.25 \mathrm{e}$ & $5.75 \pm 0.08 \mathrm{f}$ & $22.59 \pm 0.32 \mathrm{~g}$ \\
\hline
\end{tabular}

Note: Mean \pm SE values followed by same letters within each column are not significantly different at 0.05 (ANOVA and Duncan's multiple range test), $\mathrm{n}=3 . \mathrm{C}=$ control, $\mathrm{S}=0.5 \mathrm{mM}$ concentration of salicylic acid, $\mathrm{UV}_{1}=$ $15, \mathrm{UV}_{2}=30, \mathrm{UV}_{3}=60$ and $\mathrm{UV}_{4}=90$ min treatment of ultraviolet- $\mathrm{B}$ radiation, $\mathrm{UV}_{1}+\mathrm{S}, \mathrm{UV}_{2}+\mathrm{S}, \mathrm{UV}_{3}+\mathrm{S}$ and $\mathrm{UV}_{4}+\mathrm{S}$ are combined treatments of UV-B and salicylic acid.

The results pertaining to protein and sugar in seedlings are depicted in table 1 . The increase in duration of UV-B radiation from $15 \mathrm{~min}$ to $90 \mathrm{~min}$ caused progressive decrease in protein and sugar contents. A steep decline of $80.29 \%$ protein and $30.33 \%$ sugar in pea was recorded following 90 min of UV-B exposure.

The seedlings showed significant increase in activities of antioxidant enzymes viz., SOD, CAT, APX and GPX following UV-B exposure from 15 to $90 \mathrm{~min}$ (Fig. 1). The seedlings exposed to UV-B alone exhibited an increase in the activities of SOD, CAT APX and GPX by $59.78 \%, 88.76 \%, 81.56 \%$ and $62.80 \%$ respectively over the control. Simultaneous treatment with SA and UV-B caused significant improvement in the activities of SOD, CAT, APX and GPX. SA manifested positive impact on UV-B stressed seedlings to avoid oxidative damage caused by UV-B exposure.

\section{DISCUSSION}

UV-B radiation is one of the important abiotic stress factors manifesting significant impact on growth and physiological processes in plants (Mishra et al. 2009, Dwivedi et al. 2015). This problem is aggravated due to further increase in UV-B radiation in troposphere. Previously it has been demonstrated that SA priming reduced susceptibility towards different kinds of abiotic stresses by modulating defense system (Horva'th et al. 2007) Decline in seed germination under UV-B exposure was reported (Shaukat et al. 2011). Our results are in agreement with the previous findings of Shaukat et al. (2011) on Helianthus annuus. SA in low doses significantly increased seed germination in Arabidopsis under different abiotic stresses (Rajjou et al. 2006). The positive effect of SA on seed germination under abiotic stress is due to decreased level of oxidative damage (Peykarestan et al. 2012) and it also initiates translation and elongation factors, proteases and two subunits of the $20 \mathrm{~S}$ proteasome which consequently revamp seed germination by encouraging protein synthesis that are indispensable for seed germination and the movement or protein breakdown gather during the course of seed 

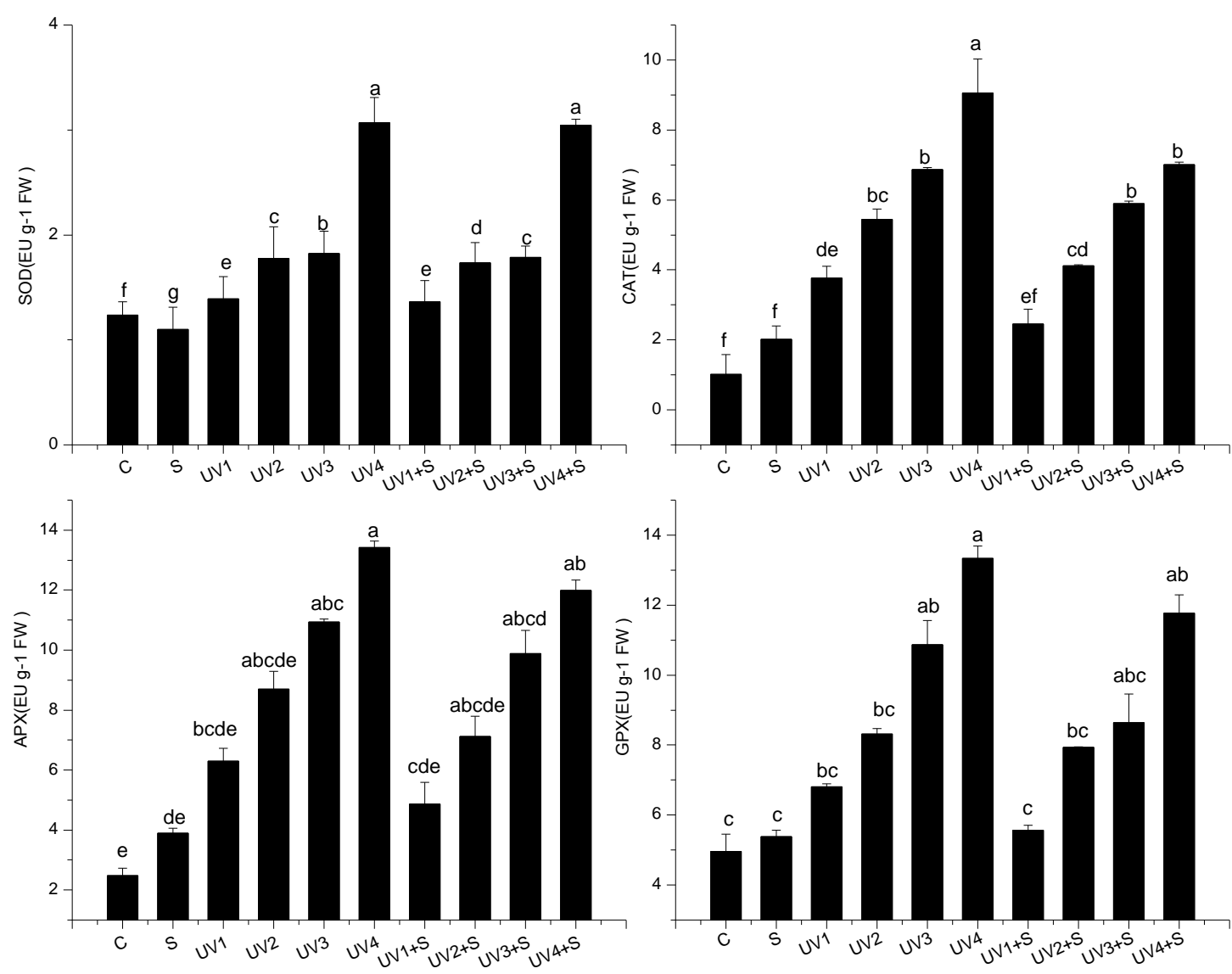

Treatments

Treatments

Figure 1. Mitigating effects of salicylic acid on antioxidant enzyme activities of UV-B stressed Pisum sativum L. Mean \pm SE values followed by same letters within each column are not significantly different at 0.05 (ANOVA and Duncan's multiple range test), $\mathrm{n}=3 . \mathrm{C}=$ control, $\mathrm{S}=0.5 \mathrm{mM}$ concentration of salicylic acid, $\mathrm{UV}_{1}=15, \mathrm{UV}_{2}=30, \mathrm{UV}_{3}=60$ and $\mathrm{UV}_{4}=90 \mathrm{~min}$ treatment of ultraviolet-B radiation, $\mathrm{UV}_{1}+\mathrm{S}, \mathrm{UV}_{2}+\mathrm{S}, \mathrm{UV}_{3}+\mathrm{S}$ and $\mathrm{UV}_{4}+\mathrm{S}$ are combined treatments of UV-B and salicylic acid.

maturation and also in the synthesis of various enzymes used in several metabolic pathways like gycolysis, glyoxylate cycle, pentose phosphate pathway, and gluconeogenesis (Rajjou et al. 2006). The results of the present study showed that UV-B alone decreased growth of pea seedlings in dose-dependent manner. The declined growth in Helianthus annuus exposed to UV-B is reported (Shaukat et al. 2011). In contrast, SA priming of seedlings /plants ameliorated the toxic effect of UV-B and promoted growth as compared to the pea seedlings exposed to UV-B treatments alone. SA pretreatment may mask impact of the UV-B response of the seedlings by modulating the antioxidant system. UV-B induced reduction in protein content of pea at higher duration of UV-B exposure may be linked with UV-B induced disturbance in protein synthesis. Like protein content we recorded reduced sugar content under UV-B stress. Seed germination and early development of seedlings exploit their storage food material (Rosa et al. 2009) and when plants are exposed to stress, some protective mechanisms can also form in plants and it requires energy and resources and the resource of energy in plants is mostly sugar (Ho 1988). Similar to our results decreased sugar content observed in maize (Correia et al. 2005) Different metabolic pathways in plants continuously produced reactive oxygen species as byproduct. Plants exposed to increased UV-B radiation induced ROS accumulation which includes not only free radicals such as superoxides but also hydrogen peroxide and singlet oxygen which caused oxidative damage to nucleic acid and proteins (Foyer et al. 1994) and metabolic system. The plants have efficient antioxidative defense system to mitigate the harmful impact of oxidative stress induced by UV-B stress. The plant defense system provides protection against free radicals and reactive oxygen species.SA pre-treatment alleviates the adverse effect of UV-B by modulating activity of antioxidant (Horva'th et al. 2007). The activities of antioxidant enzymes induced by UV-B exposure varied with plant species. Generally, activities of antioxidants like SOD, CAT, APX and GPX were found to be increased by UV-B radiation (Mishra et al. 2009, Dwivedi et al. 2015). SA treatment inhibits oxidative damage by modulating antioxidant enzymes activity and detoxifies superoxide 
radicals (Farooq et al. 2008). SOD present in different part of cell acts as first line of defense in plant. It acts first on free radicals and converts to hydrogen peroxide, CAT in peroxisomes and APX in the cell as whole have potential to convert hydrogen peroxide into water and oxygen (Noctor \& Foyer 1998). Kondo and Kawashima have also demonstrated the enhanced antioxidant activity to UV-B exposure (Kondo \& Kawashima 2000). The growth of plant is the result of equilibrium between ROS produced and antioxidant enzymes induced. Enhanced activities of antioxidant evinced the plant tolerance against UV-B radiation. Several studies reported the effect of UV-B and salicylic acid on plants but here we studied the effect of UV-B and salicylic acid on seed germination and metabolic activity of pea seedlings.

\section{CONCLUSION}

The present study showed that UV-B exposure exhibited adverse effects on seed germination, seedlings growth of Pisum sativum and their defence system. The seed priming with salicylic acid, as plant growth regulator, in appropriate concentration alleviate the adverse effects of UV-B radiation in pea seedlings.

\section{ACKNOWLEDGMENTS}

The authors are thankful to the UGC, New Delhi and University of Allahabad, Allahabad for providing financial assistance to Chanda Bano.

\section{REFERENCES}

Agrawal SB \& Mishra S (2009) Effects of supplemental ultraviolet-B and cadmium on growth, antioxidant and yield of Pisum sativum L. Ecotoxicology and Environmental Safety 72: 610-618.

Amin AA, El-Kader AAA, Shalaby MAF, Gharib FAE, Rashad ESM \& da Silva JAT (2013) Physiological effects of salicylic acid and thiourea on growth and productivity of maize plants in sandy soil. Communication in Soil Science and Plant Analysis 44: 1141-1155.

Arfan M, Athar HR \& Ashraf M (2007) Does exogenous application of salicylic acid through the rooting medium modulate growth and photosynthetic capacity in differently adapted spring wheat cultivated under salt stress? Journal of Plant Physiology 6: 685-694

Beyer WF \& Fridovich I (1987) Assaying for superoxide dismutase activity: some large consequences of minor changes in conditions. Analytical Biochemistry 161: 559-566.

Cakmak I \& Marschner H (1992) Magnesium deficiency and high light intensity enhance activities of superoxide dismutase, ascorbate peroxidase and glutathione reductase in bean leaves. Plant Physiology 98 : 1222-1227.

Casati P \& Walbot V (2003) Gene expression profiling in response to ultraviolet radiation in maize genotypes with varying flavonoid content. Plant Physiology 132: 1739-1754.

Correia CM, Pereira M, Coutinho JF, Björn Lars O, José MG \& Torres-Pereira (2005) Ultraviolet-B radiation and nitrogen affect the photosynthesis of maize: a Mediterranean field study. European Journal of Agronomy 22: 337-347.

Davies PJ (2004) The plant hormones: their nature, occurrence and function. In: Davies PJ (ed) Plant Hormones: Biosynthesis, Signal Transduction, Action, $3^{\text {rd }}$ ed. Kluwer Academic Publishers, Dordrecht, pp. $1-15$.

Dwivedi R, Singh VP, Kumar J \& Prasad SM (2015) Differential physiological and biochemical responses of two Vigna species under enhanced UV-B radiation, Journal of Radiation Research and Applied Science 8: $173-181$.

Farooq M, Aziz T, Basra SMA, Cheema MA \& Rehman H (2008b) Chilling tolerance in hybrid maize induced by seed priming with salicylic acid. Journal of Agronomy and Crop Science 194: 161-168.

Feng H, An L, Chen T, Qiang W, Xu S, Zhang M, Wang X \& Cheng G (2003) The effects of enhanced ultraviolet-B radiation on growth, photosynthesis and stable carbon isotope composition (13C) of two soybean cultivars (Glycine max) under field conditions. Environmental and Experimental Botany 49: 1-8.

Foyer CR, Lelandais M \& Kunert KJ (1994) Photooxidative stress in plants. Physiologia Plantarum 92: 696717.

Frohnmeyer H \& Staiger D (2003) Ultraviolet-B radiation-mediated responses in plants. Balancing damage and protection. Plant Physiology 133: 1420-1428. 
Hedge JE \& Hofreiter BT (1962) Estimation of carbohydrate. In: Whistler RL \& BeMiller JN (eds) Methods in Carbohydrate Chemistry. Academic Press New York, pp. 17-22.

Hemeda HM \& Klein BP (1990) Effects of naturally occurring antioxidants on peroxidase activity of vegetable extracts. Journal of Food Science 55: 184-185.

Ho LC (1988) Metabolism and compartmentation of imported sugars in sink organs in relation to sink strength. Annual Review in Plant Physiology and Plant Molecular Biology 39: 355-79.

Horva'th E, Szalai G \& Janda T (2007) Induction of abiotic stress tolerance by salicylic acid signaling. Journal of Plant Growth Regulation 26: 290-300.

Kondo N \& Kawashima M (2000) Enhancement of the tolerance to oxidative stress in cucumber (Cucumis sativus L.) seedlings by UV-B irradiation: possible involvement of phenolic compounds and antioxidative enzymes. Journal of Plant Research 113: 311-31.

Liu B, Liu XB, Li YS \& Herbert SJ (2013) Effects of enhanced UV-B radiation on seed growth characteristics and yield components in soybean. Field Crops Research 154: 158-163.

Lowry OH, Rosenbrough RJ, Farr AL \& Randall RJ (1951) Protein measurement with Folin phenol reagent. Journal of Biological Chemistry 193: 265-275.

McKenzie RL, Björn LO, Bais A \& Ilyas M (2003) Changes in biologically active ultraviolet radiation reaching the earth's surface. Photochemistry and Photobiological Science 2: 5-1.

Mishra V, Srivastava G \& Prasad SM (2009) Antioxidant response of bitter gourd (Momordica charantia L.) seedlings to interactive effect of dimethoate and UV-B irradiation. Scientia Horticulturae 120: 373-378.

Nakano Y \& Asada K (1981) Hydrogen peroxide is scavenged by ascorbate specific peroxidase in spinach chloroplasts. Plant Cell Physiology 22: 867-880.

Noctor G \& Foyer CH (1998) Ascorbate and glutathione: keeping active oxygen under control. Annual Review in Plant Physiology and Molecular Biology 49: 249-279.

Peykarestan B, Seify M, Fadaei MS \& Hatim M (2012) UV Irradiation Effects on Seed Germination and Growth, Protein Content, Peroxidase and Protease Activity in Portulaca grandiflora and Portulaca oleracea, World Applied Science Journal 17 (7): 802-808.

Rajjou L, Belghazi M, Huguet R, Robin C, Moreau A, Job C \& Job D (2006) Proteomic investigation of the effect of salicylic acid on Arabidopsis seed germination and establishment of early defense mechanisms. Plant Physiology 141: 910-923.

Ries G, Heller W, Putchta H, Sandermann H, Seidlitz HK \& Hohn B (2000) Elevated UV-B radiation reduced genome stability in plants.Nature 406: 98-101.

Rosa M, Prado C, Podazza G, Interdonato R, González JA, Hilal M \& Prado FE (2009) Soluble sugarsMetabolism, sensing and abiotic stress A complex network in the life of plants. Plant Signaling and Behaviour 4(5): 388-393.

Shaukat SS, Zaidi S \& Khan MA (2011) Effect of supplemental UV-B radiation on germination, seedling growth, and biochemical responses of sunflower (Helianthus annuus L.). Fuuast Journal of Biology 1(1): 27-33.

Zu YG, Pang HH, Yu JH, Li DW, Wei XX, Gao YX \& Tong L (2010) Responses in the morphology, physiology and biochemistry of Taxus chinensis var. mairei grown under supplementary UV-B radiation. Journal of Photochemistry and Photobiology 98: 152-158. 